\title{
Communication
}

\section{First Report of Hepatitis E Virus in Shellfish in Southeast Italy}

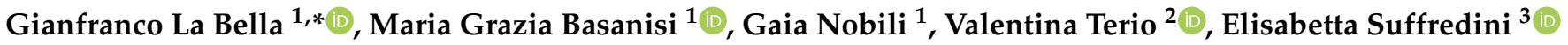 \\ and Giovanna La Salandra ${ }^{1, *}$
}

1 Istituto Zooprofilattico Sperimentale della Puglia e della Basilicata, 71121 Foggia, Italy; mariagrazia.basanisi@izspb.it (M.G.B.); gaia.nobili@izspb.it (G.N.)

2 Dipartimento di Medicina Veterinaria, Università degli Studi di Bari, 70010 Valenzano, Italy; valentina.terio@uniba.it

3 Istituto Superiore di Sanità, Dipartimento di Sicurezza Alimentare, Nutrizione e Sanità Pubblica Veterinaria-Laboratorio Nazionale di Riferimento per i Virus di Origine Alimentare, 00161 Rome, Italy; elisabetta.suffredini@iss.it

* Correspondence: gianfranco.labella@izspb.it (G.L.B.); giovanna.lasalandra@izspb.it (G.L.S.)

\section{check for}

updates

Citation: La Bella, G.; Basanisi, M.G.; Nobili, G.; Terio, V.; Suffredini, E.; La Salandra, G. First Report of Hepatitis E Virus in Shellfish in Southeast Italy. Appl. Sci. 2021, 11, 43. https://dx.doi. org/10.3390/app11010043

Received: 11 November 2020 Accepted: 21 December 2020 Published: 23 December 2020

Publisher's Note: MDPI stays neutral with regard to jurisdictional claims in published maps and institutional affiliations.

Copyright: (c) 2020 by the authors. Licensee MDPI, Basel, Switzerland. This article is an open access article distributed under the terms and conditions of the Creative Commons Attribution (CC BY) license (https: / / creativecommons.org/ licenses/by/4.0/).

\begin{abstract}
Hepatitis E virus (HEV) represents one of the principal causative agents of hepatitis globally. Among the five HEV genotypes affecting humans, genotypes 3 and 4 are zoonotic and are the main source of hepatitis $\mathrm{E}$ in developed countries. HEV has been detected in several foods. The present work investigated the presence of this virus in shellfish sold at retail in the Apulia region of Italy. The presence of HEV RNA was assessed by real-time RT-PCR in 225 shellfish samples collected during 2018. Overall, two $(0.89 \%)$ of these samples tested positive for HEV RNA. To our knowledge, this is the first notification of the detection of HEV in mussels sold at retail in the Apulia region. These data highlight the potential role of shellfish as a vehicle for the transmission of viral pathogens.
\end{abstract}

Keywords: hepatitis E virus; shellfish; food-borne; risk assessment

\section{Introduction}

Hepatitis E virus (HEV) represents one of the principal causative agents of hepatitis globally [1] and it is considered an emergent issue in industrialized regions, where transmission by contaminated food plays a key role [2]. HEV is a hepatotropic, singlestranded positive-sense RNA virus with a genome of approximately $7.2 \mathrm{~kb}$, belonging to the Hepeviridae family, genus Orthohepevirus, Orthohepevirus A species [3,4]. Five of the eight genotypes of Orthohepevirus A (HEV-1, 2, 3, 4, and 7) infect humans [4]. HEV can exist in two forms: non-enveloped or "quasi-enveloped" [3]. All HEV genotypes belong to a single serotype [5]. The human viruses HEV-1 and HEV-2 genotypes are highly endemic in developing regions, including various regions of Africa, Asia, the Middle East, and Mexico, and are diffused through contaminated water. These viruses are accountable for a great number of outbreaks and cause severe hepatitis during pregnancy [6]. By contrast, genotypes 3 and 4 are revealed in both animals and humans and are the principal causes of hepatitis $\mathrm{E}$ in humans in several developed countries [7].

The World Health Organisation (WHO) has estimated that 20 million persons worldwide are newly infected with HEV annually, with 3.3 million developing acute hepatitis E and 70,000 dying of HEV-related causes [8]. Over the last decade, HEV infection has been reported to cause more than 21,000 cases of hepatitis E, with 28 deaths, in the European Union (EU), where food-borne transmission seems to be the major path of infection [9]. These data do not reflect the real number of infected people in the EU because HEV infection is not required to be reported to public health authorities in all member states of the EU, and the surveillance systems differ among countries.

In Italy, the number of individuals infected with HEV increased during the years 20072018, as well as doubling from 2018 to 2019, although not all regional laboratories are able to specifically differentiate HEV from other hepatitis viruses. Moreover, a peak of cases was 
reached in 2019 when the number of cases doubled compared to the previous year [10]. In European countries, HEV genotype 3 is the most prevalent HEV genotype infecting humans, with relatively few patients being infected with genotype 4 . These genotypes are thought to be transmitted through foods, especially the consumption of undercooked or raw pig, wild boar, and deer meat [9]. Domestic swine appear to represent the principal source of zoonotic HEV transmission in Europe and are considered the main viral reservoir $[9,11]$. The European Food Safety Authority has estimated that HEV can be transmitted to humans by the consumption of foods composed of meat from an infected animal and by foodstuffs fouled with HEV [9]. For the latter, virus shedding by feces (animal and human) represents an important public health risk. Indeed, environmental contamination, including contamination of organic fertilizers and water, can provide a source for HEV contamination of other foods, including shellfish, soft fruits, and leafy green vegetables [12]. In the feeding process, by filtering from their marine environment, shellfish can concentrate viral particles, becoming a potential source of human infection [13]. Although the consumption of raw shellfish, liver sausage, and wild boar meat was recognized as a hazard factor for locally acquired HEV infection in Italy [5], only a small number of surveys to date have evaluated the presence of HEV in shellfish for human consumption [13-17].

The Apulia region of southeast Italy, with an $860 \mathrm{~km}$ coastline [18], is a major source of shellfish for consumption throughout Italy. Shellfish are usually consumed in the undercooked or raw state in the Apulia region. To our knowledge, however, no survey to date has assessed the attendance of HEV in mussels sold at retail in the Apulia region. The present study, therefore, evaluated whether HEV could be detected in shellfish sold at retail in the Apulia region, and assessed the potential risk of HEV transmission associated with shellfish consumption.

\section{Materials and Methods}

A total of 225 samples of different species of shellfish commercially sold in the Apulia region were collected from January to December 2018. These samples included mussels (Mytilus galloprovincialis, $n=182$ ), oysters (Crassostrea gigas, $n=32$ ), and other species, including Modiolus barbatus $(n=5)$, Tapes decussates $(n=2)$, Solen marginatus $(n=2)$, Aequipecten opercularis $(n=1)$, Callista chione $(n=1)$. The geographic origins of these shellfish samples are shown in Table 1.

Table 1. Geographic origins of the tested shellfish samples.

\begin{tabular}{|c|c|c|c|c|c|c|}
\hline \multirow[b]{2}{*}{ Species } & \multicolumn{5}{|c|}{ Origin } & \multirow[b]{2}{*}{ Total } \\
\hline & Italy & Spain & Greece & $\begin{array}{l}\text { The } \\
\text { Netherlands }\end{array}$ & France & \\
\hline $\begin{array}{c}\text { Mytilus } \\
\text { galloprovincialis }\end{array}$ & 157 & 16 & 9 & & & 182 \\
\hline Crassostrea gigas & 12 & & & 14 & 6 & 32 \\
\hline Modiolus barbatus & 5 & & & & & 5 \\
\hline Tapes decussates & 2 & & & & & 2 \\
\hline Solen marginatus & 2 & & & & & 2 \\
\hline $\begin{array}{c}\text { Aequipecten } \\
\text { opercularis }\end{array}$ & 1 & & & & & 1 \\
\hline Callista chione & 1 & & & & & 1 \\
\hline Total & 180 & 16 & 9 & 14 & 6 & 225 \\
\hline
\end{tabular}

All samples were collected by local health services, in accordance with national official monitoring activities for microbiological criteria of shellfish (e.g., Salmonella and Escherichia coli). All the collected samples were transported to the Istituto Zooprofilattico Sperimentale della Puglia e della Basilicata (Foggia, Italy) and stored at $4{ }^{\circ} \mathrm{C}$ until analyzed. The presence of HEV was determined as described [13], using a method that follows the structure and quality criteria of the standardized ISO 15216-2:2019 method [19]. Briefly, 
15-60 specimens of each sample were casually chosen, and their digestive tissue was cut up, cleaned, and shredded with a sterile blade. Following digestion, $2 \mathrm{~mL}$ proteinase $\mathrm{K}$ $\left(0.1 \mathrm{mg} / \mathrm{mL}\right.$ ) and $10 \mu \mathrm{L}$ of mengovirus clone $\mathrm{MC}_{0}$ as process control (supplied by the Istituto Superiore di Sanità, Rome, Italy) were added to an aliquot of $2.0 \mathrm{~g}$ of each sample, and incubated at $37^{\circ} \mathrm{C}$ for $60 \mathrm{~min}$ with shaking, and then at $60^{\circ} \mathrm{C}$ for $15 \mathrm{~min}$ to deactivate the enzyme. After centrifugation at $3000 \times g$ for $5 \mathrm{~min}$, the supernatants were recovered. Viral nucleic acids were extracted employing the Nuclisens extraction kit (BioMerieux, Paris, France) according to the manufacturer's protocol, and the eluted RNA (100 $\mu \mathrm{L})$ was immediately analyzed or stocked at $-80^{\circ} \mathrm{C}$ until use.

Real-time RT-PCR for HEV was carried out on a 7500 Fast Real-Time PCR system thermocycler (Applied Biosystems, CA, USA) using an RNA UltraSense One-Step Quantitative RT-PCR System (Life Technologies, Carlsbad, CA, USA), and primers and probe targeting the ORF3 region of HEV [20,21].

The thermal cycling conditions were $50^{\circ} \mathrm{C}$ for $60 \mathrm{~min}$ and $95^{\circ} \mathrm{C}$ for $5 \mathrm{~min}$, followed by 45 cycles of $95^{\circ} \mathrm{C}$ for $15 \mathrm{~s}, 60^{\circ} \mathrm{C}$ for $1 \mathrm{~min}$, and $65^{\circ} \mathrm{C}$ for $1 \mathrm{~min}$. An external amplification control (in vitro synthesized RNA supplied by the Istituto Superiore di Sanità, Rome, Italy) was added to the samples to evaluate the presence of PCR inhibitors. Samples found to be HEV positive were retested (another aliquot of digestive tissue from the same pooled samples) at an independent laboratory as described [22], both for confirmation (i.e., to rule out false-positive results) and for quantification, according to Di Pasquale et al. 2019 [22], with the results defined as the number of HEV genome copies (gc) per gram of digestive tissue, and calculated according to the standardized ISO 15216-1:2017 method [23]. In detail, the quantification was done using a linearized plasmid containing the target sequence of HEV to generate the standard curve. Analyses were performed in duplicate and the average concentration of the two replicate reactions were used for quantification. All samples that tested close to or below the LOD of the real-time RT-(q) PCR assay were retested in quadruplicate reactions; only samples in which at least two wells that showed amplification were considered positive [22]. Positive samples were subjected to HEV genotyping by nested RT-PCR amplification of a portion of the ORF1 region [24].

\section{Results and Discussion}

Of the 225 shellfish samples tested, two $(0.89 \%)$ were positive for HEV RNA by real-time RT-PCR. These two samples included one (0.5\%) of the 182 samples of $M$. galloprovincialis tested and one (3.1\%) of the $32 \mathrm{C}$. gigas samples tested. The levels of virus were slightly below the limit of quantification of the method $\left(3.9 \times 10^{2} \mathrm{gc} / \mathrm{g}\right)$ with estimated concentrations of $2.5 \times 10^{2}$ in the mussel sample and $7.0 \times 10^{1} \mathrm{gc} / \mathrm{g}$ in the oyster sample (Table 2).

Because of the small sample size, HEV prevalence did not differ significantly among the different bivalve species (Fischer's exact test; $p>0.05$ ). The two HEV positive samples originated from two distinct locations, with the mussel sample taken in the northern part of Apulia and the oyster sample taken in the southern part of Apulia. Interestingly, both positive samples were collected during spring 2018 (Table 2). However, multi-year sampling is needed to evaluate the significance of a supposed seasonal pattern.

Attempts to genotype the two positive samples were unsuccessful, as the conventional nested RT-PCR amplification yielded negative results. This may be related to the low concentration of HEV in the two samples (Table 2), roughly corresponding to $<1 \mathrm{gc} / \mu \mathrm{L}$ in the tested RNA. 
Table 2. Sampling date, city, Cq values, and HEV concentrations (genome copies/g) of the samples positive for HEV RNA.

\begin{tabular}{cccccc}
\hline Sample ID & City & $\begin{array}{c}\text { Sampling Date } \\
\text { (Day/Month/Year) }\end{array}$ & Species & Cq Value & $\begin{array}{c}\text { HEV Concentration } \\
\text { (Genome Copies/g) }\end{array}$ \\
\hline 2882 & Fasano & $27 / 03 / 2018$ & $\begin{array}{c}\text { Mussel } \\
\text { (Mytilus } \\
\text { galloprovincialis) } \\
\text { Oyster } \\
\text { (Crassostrea gigas) }\end{array}$ & 38.5 & $\approx 2.5 \times 10^{2}$ \\
\hline
\end{tabular}

Viral infections have been linked to shellfish consumption, often due to undercooking of the product and sewage contamination of harvesting areas [25]. Despite shellfish consumption being a risk factor for HEV infection [13], hepatitis E following shellfish consumption has been relatively rare [26]. Several studies in Europe have reported variations in the presence of HEV in mussels harvested from regulated waters, with rates of contamination of $2.9 \%$ [12], $14.8 \%$ [11], and $24.4 \%$ [27], whereas other studies have reported no evidence of HEV. In Italy, HEV has been observed in commercially harvested shellfish, with prevalence rates ranging from $0.9 \%$ in Sicily [17] to $2.6 \%$ in the Campania region [13]. The low prevalence ratio reported in this survey was comparable to that of shellfish from Sicily [17]. One study found that HEV was present in $8.1 \%$ of mussels from Italy, although that study included bivalves that were collected from areas not approved for harvesting [28]. HEV has been detected in the environment in Italy, including in sewage [29], river waters [15], and recently, in coastal waters [13].

The detected levels of HEV RNA shown in the present work were slightly below $10^{2}$ genome copies/g tissue, in agreement with other European studies on shellfish. Two studies in northwestern Spain reported contamination levels varying from $6.7 \times 10^{1}$ to $8.6 \times 10^{4} \mathrm{gc} / \mathrm{g}$ [11] and from non-quantifiable to $1.1 \times 10^{5} \mathrm{gc} / \mathrm{g}$ [24]. In the latter study, $19.5 \%$ of positive samples presented viral genome copies below the limit of quantification, and one had a concentration of $4.0 \times 10^{2} \mathrm{gc} / \mathrm{g}$. A study from Scotland also reported a very low virus concentration in commercial mussels with only one sample quantifiable at $<10^{2} \mathrm{IU} / \mathrm{mL}$ [12], and a study from Italy showed that concentrations of HEV in shellfish were always below $10^{2} \mathrm{gc} / \mathrm{g}$ [13]. Although a low concentration was estimated in the present study $\left(2.5 \times 10^{2}\right.$ and $\left.7.0 \times 10^{1} \mathrm{gc} / \mathrm{g}\right)$, this cannot be overlooked. For other foodborne viruses, several surveys on shellfish-related outbreaks showed as very low viral genome levels $(10-100 \mathrm{gc} / \mathrm{g})$ were correlated to the probability of infections with NoV or HAV $[30,31]$. Contrary, for HEV there are current data gaps regarding the relationship between genome copies numbers and infective dose [32].

The existence of HEV in shellfish may be associated with the pollution of the shellfish harvesting area by swine waste and urban sewage [11,12]. The increasing number of patients in Italy with hepatitis E over the last years [10] may support the recent reports of HEV in shellfish. Similar to other enteric viruses, variations in the prevalence of HEV may result from differences in contamination levels of shellfish harvesting areas. These differences in contamination may be caused by geographical (e.g., distances from the seacoast, rivers, and estuaries) and environmental (e.g., sewage discharge) factors [18].

Because of the small number of positive samples, differences in HEV prevalence among bivalve species could not be calculated. A similar result was obtained in a study conducted in Spain [27]. Further studies are needed to assess possible differences in contamination among bivalve species. In this study, no data on genotype were obtained from the two positive samples. The absence of amplification by nested RT-PCR confirms the lower sensitivity of conventional PCR compared with real-time RT-PCR assays, especially in food samples with low levels of contamination [9]. In particular, the assay utilized in this study [20] has been reported to be more sensitive than other RT-qPCR assays [9]. It is tricky to achieve a helpful sequence from positive real-time RT-PCR food specimens, due to several factors (e.g., failure of identification by the conventional primers, concomitant amplification of various strains, virus concentration below the limit of detection of 
traditional reverse transcription PCR, not enough extraction of clean RNA suited for sequencing) [32]. Earlier studies carried out in Italy showed that HEV genotype 3 was present in shellfish $[13,17,28]$. Because this genotype is the most common in Italy, it was likely present in our positive samples. However, further investigations are needed to confirm this assumption.

\section{Conclusions}

The present survey is, to our knowledge, the first showing the presence of HEV in shellfish commercially available in the Apulia region of southeast Italy highlighting that these foods may play a potential part in the spreading of viral pathogens. Further investigations, especially of major shellfish harvesting areas in the Apulia region, may provide more information about the spread and genotypes of HEV in the environment of southeast Italy, as well as determining possible differences among bivalve species or seasonal patterns. Furthermore, continual surveillance, quantitative data, and evaluation of infectivity of detected viruses are necessary to more precisely estimate the risks associated with HEV in foods.

Author Contributions: Conceptualization, formal analysis, writing and editing, G.L.B.; formal analysis and review, M.G.B., G.N. and V.T.; supervision and review, E.S., G.L.S. All authors have read and agreed to the published version of the manuscript.

Funding: This research was funded by the Ministero della Salute, IZSPB 03/19 RC.

Acknowledgments: The authors gratefully acknowledge Rosa Coppola and Annita Damato from IZSPB for their technical support.

Conflicts of Interest: The authors declare no conflict of interest.

\section{References}

1. Mulder, A.C.; Kroneman, A.; Franz, E.; Vennema, H.; Tulen, A.D.; Takkinen, J.; Hofhuis, A.; Adlhoch, C. Members of HEVnet. HEVnet: A One Health, collaborative, interdisciplinary network and sequence data repository for enhanced hepatitis $\mathrm{E}$ virus molecular typing, characterisation and epidemiological investigations. Eurosurveillance 2019, 24, 1800407. [CrossRef] [PubMed]

2. Di Pasquale, S.; Cozzi, L.; Lena, R.; Di Sandro, A.; De Magistris, I.; De Medici, D.; Johne, R.; Suffredini, E. Development of a viability PCR assay for the analysis of Hepatitis E virus in food matrices. Eur. J. Public Health 2018, 28, 454. [CrossRef]

3. Denner, J. Hepatitis E virus (HEV)-The Future. Viruses 2019, 11, 251. [CrossRef] [PubMed]

4. Johne, R.; Dremsek, P.; Reetz, J.; Heckel, G.; Hess, M.; Ulrich, R.G. Hepeviridae: An expanding family of vertebrate viruses. Infect. Genet. Evol. 2014, 27, 212-229. [CrossRef]

5. La Rosa, G.; Muscillo, M.; Spuri Vennarucci, V.; Garbuglia, A.R.; La Scala, P.; Capobianchi, M.R. Hepatitis E virus in Italy: Molecular analysis of travel-related and autochthonous cases. J. Gen. Virol. 2011, 92, 1617-1626. [CrossRef]

6. Kamar, N.; Izopet, J.; Pavio, N.; Aggarwal, R.; Labrique, A.; Wedemeyer, H.; Dalton, H.R. Hepatitis E virus infection. Nat. Rev. Dis. Primers 2017, 3, 17086. [CrossRef]

7. Pavio, N.; Meng, X.J.; Doceul, V. Zoonotic origin of hepatitis E. Curr. Opin. Virol. 2015, 10, 34-41. [CrossRef]

8. WHO. Weekly Epidemiological Record. 12 December 2014, 89th year. No. 50. 2014, Volume 89, pp. 561-576. Available online: https:/ /www.who.int/wer/2014/wer8950/en/ (accessed on 22 November 2019).

9. $\quad$ EFSA BIOHAZ Pnael (EPoBH); Ricci, A.; Allende, A.; Bolton, D.; Chemaly, M.; Davies, R.; Fernandez Escamez, P.S.; Herman, L.; Koutsoumanis, K.; Lindqvist, R.; et al. Scientific Opinion on the public health risks associated with hepatitis E virus (HEV) as a food-borne pathogen. EFSA J. 2017, 15, e04886.

10. SEIEVA. Bollettino SEIEVA. Epidemiologia Delle Epatiti Virali Acute in Italia. Numero 6 Aggiornamento 2019. 2020. Available online: https:/ / www.epicentro.iss.it/epatite/dati-seieva\#te (accessed on 25 July 2020).

11. Mesquita, J.R.; Oliveira, D.; Rivadulla, E.; Abreu-Silva, J.; Varela, M.F.; Romalde, J.L.; Nascimento, M.S.J. Hepatitis E virus genotype 3 in mussels (Mytilus galloprovinciallis), Spain. Food Microbiol. 2016, 58, 13-15. [CrossRef]

12. O'Hara, Z.; Crossan, C.; Craft, J.; Scobie, L. First Report of the Presence of Hepatitis E Virus in Scottish-Harvested Shellfish Purchased at Retail Level. Food Environ. Virol. 2018, 10, 217-221. [CrossRef]

13. La Rosa, G.; Proroga, Y.T.R.; De Medici, D.; Capuano, F.; Iaconelli, M.; Della Libera, S.; Suffredini, E. First Detection of Hepatitis E Virus in Shellfish and in Seawater from Production Areas in Southern Italy. Food Environ. Virol. 2018, 10, 127-131. [CrossRef] [PubMed]

14. La Rosa, G.; Fratini, M.; Spuri Vennarucci, V.; Guercio, A.; Purpari, G.; Muscillo, M. GIV noroviruses and other enteric viruses in bivalves: A preliminary study. New Microbiol. 2012, 35, 27-34. [PubMed] 
15. Iaconelli, M.; Purpari, G.; Libera, S.D.; Petricca, S.; Guercio, A.; Ciccaglione, A.R.; Bruni, R.; Taffon, S.; Equestre, M.; Fratini, M.; et al. Hepatitis A and E Viruses in Wastewaters, in River Waters, and in Bivalve Molluscs in Italy. Food Environ. Virol. 2015, 7, 316-324. [CrossRef] [PubMed]

16. Fusco, G.; Di Bartolo, I.; Cioffi, B.; Ianiro, G.; Palermo, P.; Monini, M.; Amoroso, M.G. Prevalence of Foodborne Viruses in Mussels in Southern Italy. Food Environ. Virol. 2017, 9, 187-194. [CrossRef] [PubMed]

17. Purpari, G.; Macaluso, G.; Di Bella, S.; Gucciardi, F.; Mira, F.; Di Marco, P.; Lastra, A.; Petersen, E.; La Rosa, G.; Guercio, A. Molecular characterization of human enteric viruses in food, water samples, and surface swabs in Sicily. Int. J. Infect. Dis. 2019, 80, 66-72. [CrossRef] [PubMed]

18. La Bella, G.; Martella, V.; Basanisi, M.G.; Nobili, G.; Terio, V.; La Salandra, G. Food-Borne Viruses in Shellfish: Investigation on Norovirus and HAV Presence in Apulia (SE Italy). Food Environ. Virol. 2017, 9, 179-186. [CrossRef]

19. International Organization for Standardization. Iso/ts 15216-2 Microbiology of Food Chain. Horizontal Method for Determination of Hepatitis a Virus and Norovirus Using Real-Time rt-pcr. Part 2: Method for Detection; International Organization for Standardization: Geneva, Switzerland, 2019.

20. Jothikumar, N.; Cromeans, T.L.; Robertson, B.H.; Meng, X.J.; Hill, V.R. A broadly reactive one-step real-time RT-PCR assay for rapid and sensitive detection of Hepatitis E virus. J. Virol. Methods 2006, 131, 65-71. [CrossRef]

21. Garson, J.A.; Ferns, R.B.; Grant, P.R.; Ijaz, S.; Nastouli, E.; Szypulska, R.; Tedder, R.S. Minor groove binder modification of widely used TaqMan probe for hepatitis E virus reduces risk of false negative real-time PCR results. J. Virol. Methods 2012, 186, 157-160. [CrossRef]

22. Di Pasquale, S.; De Santis, P.; La Rosa, G.; Di Domenico, K.; Iaconelli, M.; Micarelli, G.; Martini, E.; Bilei, S.; De Medici, D.; Suffredini, E. Quantification and genetic diversity of Hepatitis E virus in wild boar (Sus scrofa) hunted for domestic consumption in Central Italy. Food Microbiol. 2019, 82, 194-201. [CrossRef]

23. International Organization for Standardization. Iso/ts 15216-1 Microbiology of the Food Chain. Horizontal Method for Determination of Hepatitis a Virus and Norovirus Using Real-Time rt-pcr. Part 1: Method for Quantification; International Organization for Standardization: Geneva, Switzerland, 2017.

24. Fogeda, M.; Avellón, A.; Cilla, C.G.; Echevarría, J.M. Imported and autochthonous hepatitis E virus strains in Spain. J. Med. Virol. 2009, 81, 1743-1749. [CrossRef]

25. Bellou, M.; Kokkinos, P.; Vantarakis, A. Shellfish-borne viral outbreaks: A systematic review. Food Environ. Virol. 2013, 5, 13-23. [CrossRef] [PubMed]

26. Said, B.; Ijaz, S.; Kafatos, G.; Booth, L.; Thomas, H.L.; Walsh, A.; Ramsay, M.; Morgan, D. Hepatitis E outbreak on cruise ship. Emerg. Infect. Dis. 2009, 15, 1738-1744. [CrossRef] [PubMed]

27. Rivadulla, E.; Varela, M.F.; Mesquita, J.R.; Nascimento, M.S.J.; Romalde, J.L. Detection of hepatitis E virus in shellfish harvesting areas from Galicia (northwestern Spain). Viruses 2019, 11, 618. [CrossRef] [PubMed]

28. Donia, D.; Dell'Amico, M.C.; Petrinca, A.R.; Martinucci, I.; Mazzei, M.; Tolari, F.; Divizia, M. Presence of hepatitis E RNA in mussels used as bio-monitors of viral marine pollution. J. Virol. Methods 2012, 186, 198-202. [CrossRef]

29. Iaconelli, M.; Bonanno Ferraro, G.; Mancini, P.; Suffredini, E.; Veneri, C.; Ciccaglione, A.R.; Bruni, R.; Della Libera, S.; Bignami, F.; Brambilla, M.; et al. Nine-Year Nationwide Environmental Surveillance of Hepatitis E Virus in Urban Wastewaters in Italy (2011-2019). Int. J. Environ. Res. Public Health 2020, 17, 2059. [CrossRef]

30. Teunis, P.F.M.; Moe, C.L.; Liu, P.E.; Miller, S.; Lindesmith, L.; Baric, R.S.; Le Pendu, J.; Calderon, R.L. Norwalk virus: How infectious is it? J. Med. Virol. 2008, 80, 1468-1476. [CrossRef]

31. Pintó, R.M.; Costafreda, M.I.; Bosch, A. Risk assessment in shellfish-borne outbreaks of hepatitis A. Appl. Environ. Microbiol. 2009, 75, 7350-7355. [CrossRef]

32. Bosch, A.; Gkogka, E.; Le Guyader, F.S.; Loisy-Hamon, F.; Lee, A.; van Lieshout, L.; Marthi, B.; Myrmel, M.; Sansom, A.; Schultz, A.C.; et al. Foodborne viruses: Detection, risk assessment, and control options in food processing. Int. J. Food Microbiol. 2018, 285, 110-128. [CrossRef] 